\title{
Sustainable Development and Water: Source of Conflict or Opportunity for Cooperation
}

\author{
Dr. Neeta Rani
}

Assistant Professor, Dept. of National Security Studies, Central University of Jammu, Jammu Raya Suchani (Bagla), District Samba, Jammu-181143, J\&K, India neetam29@gmail.com

\begin{abstract}
Water is an important component of sustainable development; without it survival is not possible. Though it is available in great quantity but accessibility to fresh water is limited, which makes it an important element for lives. Water supply has become unhygienic to people due to reasons like lack of economic infrastructure and poor conditions. There are several countries in the world which face acute water shortage as well as poor water quality. It hampers their water security and also brings negative impacts on food security and the livelihood of people as well. Lack of water resources invites droughts which further make lives of people more miserable, exacerbate starvation and causes malnutrition. Global warming has made water a restricted resource which is very much important for human lives. Therefore the proper management of water resources is must to bring sustainable development. Water plays a vital role in strengthening the economic and social existence of human beings.
\end{abstract}

Keywords: Water conflicts, Development, Water sharing, Cooperation, Rivers

\section{INTRODUCTION}

"Sustainable development is development that meets the needs of the present without compromising the ability of future generations to meet their own needs."

- Brundtland Commission (1983)

Water is a finite source; 3 percent of the world's total water resources are fresh (not saline) of which one third is inaccessible for various reasons (Chaturvedi, 2013). Human beings need minimum five gallons of water per day to meet their basic needs (Clinton, 2010). Every country is trying to acquire freshwater resources which are very much important for the survival of the people residing therein. There is an urgent need for hygienic water supply. Water gives life but the sustainability of the same has become one of the greatest challenges for many countries these days. The budding population, energy demands, climate change, agricultural production, pollution etc make the consistent water supply more complicated. Further, lack or excess of rains and monsoons contribute to the misery. All these factors and recoiling of water resources contribute to decline in the social, economic and environmental security. World Bank has already warned that lack of water will be the major factor restricting the economic development in the coming decades (Serageldin, 1995). Moreover, over pumping of water is also leading to reduction in ground water levels.

Global warming and mishandling of water resources lead to shrinking of water resources in many countries in the world. Water evaporation from the ground is also contributing to water scarcity in the arid countries. The thirst of the atmosphere (evaporation) diminishes the availability of water on earth surface (Marquette, 2009). Moreover, the availability of water resources is not only affected by climatic conditions, but it also gets affected due to changes in the environment such as rapid deforestation. The deforestation leads to erosion of soil as well as lowering the water retaining capacity of the soil (Molen \& Hildeering, 2005). Tao F. et al in an 
article 'Future Climate change, the agriculture water cycle and agriculture production in China' have discussed influence of climate change, "The water cycle is an integrated and dynamic component of the earth's geographical system and both affects and is affected by climate conditions. Changes in the earth's radiation balance affect winds, temperatures, atmospheric energy and water transport, cloud dynamics and more. Changes in temperature affect evaporation and transpiration rates, cloud characteristics and extent, soil-moisture and snowfall and snowmelt regimes. Changes in precipitation affect the timing and magnitude offloods and droughts, and shift runoff regimes. Synergistic effects will alter cloud formation, soil and water conditions, vegetation patterns and growth rates."(Tao et al, 2003).

The quality of the surface and ground water too is deteriorating day by day. The way people are putting waste in the water reservoirs has made it unusable for drinking or other purposes. Water is an important source for living. It also contributes in the development of countries too. United Nations Water Conference held at Mar Del Plata in 1977 confirmed the significance of water as a vital element for the development of many countries in the world (Koudstaal, 1992, 277).

There is a possibility that the water related problems may increase in the coming future. These problems cannot be solved with a single global strategy especially when the world is focusing more on the problems like disappearance of some species, reduction of forest lands and other environmental issues and concerns etc. Earth's surface has 70 percent water but out of this only three percent is fresh water which can be used for living beings. Three quarters of the world's population do not have an access to hygiene drinking water (Koudstaal \& Rijsberman, 1992). The available amount of fresh water is inaccessible for human use due to various reasons (Lefort, 1996). Nearly 0.01 percent of the total water supply is considered as usable for human beings on regular basis (Hinrichsen \& Tacio, 2002).

\section{Statement of the Problem}

Water is so much important to all living beings that they can fight or go for war over sharing these resources. Many countries have been involved in several conflicts for sharing of water resources and further the depletion of water resources day by day and increased pollution has made the scenario more complicated. Their survival is based on the availability of fresh water and countries can find various opportunities for cooperation which can lessen the conflicts among these.

\section{ОВJECTIVES}

The study has following objectives:-

- To analyse conflicts erupting over sharing of water in the world.

- To examine the possibilities of cooperation on water sharing among countries.

\section{Methodology}

The study is based on secondary data. The data were collected from various reports and agreements, journals, books and internet sources. The data has been analysed with different statistical tools.

\section{Scarcity of Water Resources}

Robert Ambroggi, an American Hydrologist, once stated that "the total quantity of water on the earth exceeds all conceivable needs of the human population."(Godschalk, 2007) Although his statement does not fit in the present context as water is a scarce natural resource. Very less amount of fresh water is available on the Earth which can be used by humans whereas the remaining has been staying on earth in the form of glaciers, snow etc. The fresh water itself is a significance natural resource as the survival of living beings and the development 
of civilization cannot happen without clean water availability (Godschalk, 2007). But the main issue is that it has been distributed unequally. Some places in the world have abundance of water resources, but others face shortage of the same (Godschalk, 2007). Seasonal rains also contribute to the fresh water supplies in many countries. Water can be useful only if it is available at the right time along with the required quantity. If it is not sufficient and the timing of its availability is wrong (such as flood situations) then it can be a burden to human activities. Many countries are facing water scarcity problem as their population increase, urbanization is taking place everywhere and so is the increase in water consumption.

\section{Water Pollution}

Water pollution has declined the capacity of waterways to flush pollutants from its distribution system. Every year a huge amount of wastage is being discharged in to the rivers, lakes and other water resources all around the world. The countries which are industrialized suffer more water pollution related problems; European countries and North America are among these. Europe Rivers have nitrate concentrations mainly from agrochemicals. The level of ground water pollution is also reaching to a worsening stage. Further it may likely to be contaminated with poisons from pesticides and fertilizers covering nearly 60, 000 square kilometres of groundwater aquifers (Niemczynowicz, 1996). Pollution is a worrisome problem for the countries where population is on rise and the development is in process. Moreover, the government cannot afford to spend money on sanitation projects and waste treatment facilities in these countries. In most of the developing countries, nearly 90 percent of domestic sewage and 75 percent of industrial waste is released in surface waters without any treatment facilities. (Carty, 1991) It is estimated that 80 percent of the diseases are related to unsafe water availability in the developing countries.( Molen \& Hildeering, 2005) It is very easy to dump industrial waste and pollutants (like wastes from chemical plants) directly into waterways these days. Agriculture sector also contributes on a larger scale in water pollution. The use of fertilizers and pesticides has contaminated the groundwater as well as surface water. It has also contributed to the degradation of water quality. It is very important for the near future requirements to sustain all the water (fresh) resources available.

\section{WATER CONFLiCT AND COOPERATION}

Civilization and humanity depend on available freshwater resources for various needs like domestic, livelihood, food and agricultural production, cultural practices, power generation, industrial manufacturing etc. Water resources are limited in nature and are subject to change over time and space due to precipitation and temperature cycles. Every now and then availability of freshwater resources is becoming unpredictable as a result of global warming and climate change.

Nearly 200 river basins in the world are shared by either two or more than two countries and approximately 40 percent population lives along with these which shares water with each other. The sharing of water resources (especially fresh water resources) itself is a conflict among people since the beginning of humankind. Being a fugitive resource, the availability of fresh water keeps on changing with time and space (Godschalk, 2007).

Many endeavours are being made to divert or alter water resources to fulfil the necessities which, further, lead to conflicts. The scarcity of water can and will lead directly to warfare between nations in the near future as they say future wars will occur over water sharing. Even today, there are many countries in the world which have been involved in conflicts over water resources. Water conflict can be defined as oral or militarily actions aggressively between the conflicting parties over the divided/shared water resources. In India, several states are fighting over water sharing resources. In order to achieve sustainable development, the management of water resources needs inventive as well as flexible approaches so that cooperation can take place between the conflicting parties. 
Sustainable Development and Water: Source of Conflict or Opportunity for Cooperation

\section{Why Conflict?}

As mentioned earlier, the entire history of humankind has seen conflict over natural resources; water is the one of these. It is a necessity of life and to survive one needs water along with other resources. There's a statement given by Ismael Seragelin (in 1995), former World Bank Vice president for Environmentally Sustainable Development, which highlights the future conflicts arising due to sharing of and decline in water resources. He said quoted "Wars of the next century will be over water. not oil." (Godschalk, 2007) Though no wars related to the access of fresh water resources has been fought till now and based on this fact some experts falsify the idea of future water wars. But another fact is also there that a country can go for a war when the issue is strategically important and when there is no other option available/left for the same (Godschalk, 2007). Any country can go for a war if it affects its survival for long term. The perceptions of security changed post cold war and water security has already become an important component of security. The concept of "water wars" as a major threat of international conflict emerged with Joyce Starr's Foreign Policy article in 1991 (Ohlsson, 2009).

When the interests of conflicting parties or their water security is at stake and threatened, there are chances of conflict to be occurred or may be when one of the parties does wrong in sharing water even then also conflict can take place. Moreover these days the water resources are under considerable strain as the level of water has begun to drop and there is a concern of increased pollution in many of the water reserves.

The term water security means when there is a threat to sustainable and secure water utilization from both natural and manmade forces on water resources. It is also society's ability to ensure sustainable access to safe, hygiene and sufficient water resources. A number of developed countries are facing water shortages which include United Kingdom, Belgium, Singapore and Poland. Even the United States has also faced tension over water resources both for agricultural purposes and for urban utilization.

There have been several examples of countries which are dependent on other/neighbouring countries for water resources. Six European countries (Switzerland, Liechtenstein, Austria, Germany, France and Netherlands) share the water content of Rhine River. Nile River, the longest river in the world, is a source of life for countries like Rwanda, Burundi, Uganda, Congo DR, Tanzania, Kenya, Ethiopia, Eritrea, South Sudan, Sudan and Egypt.

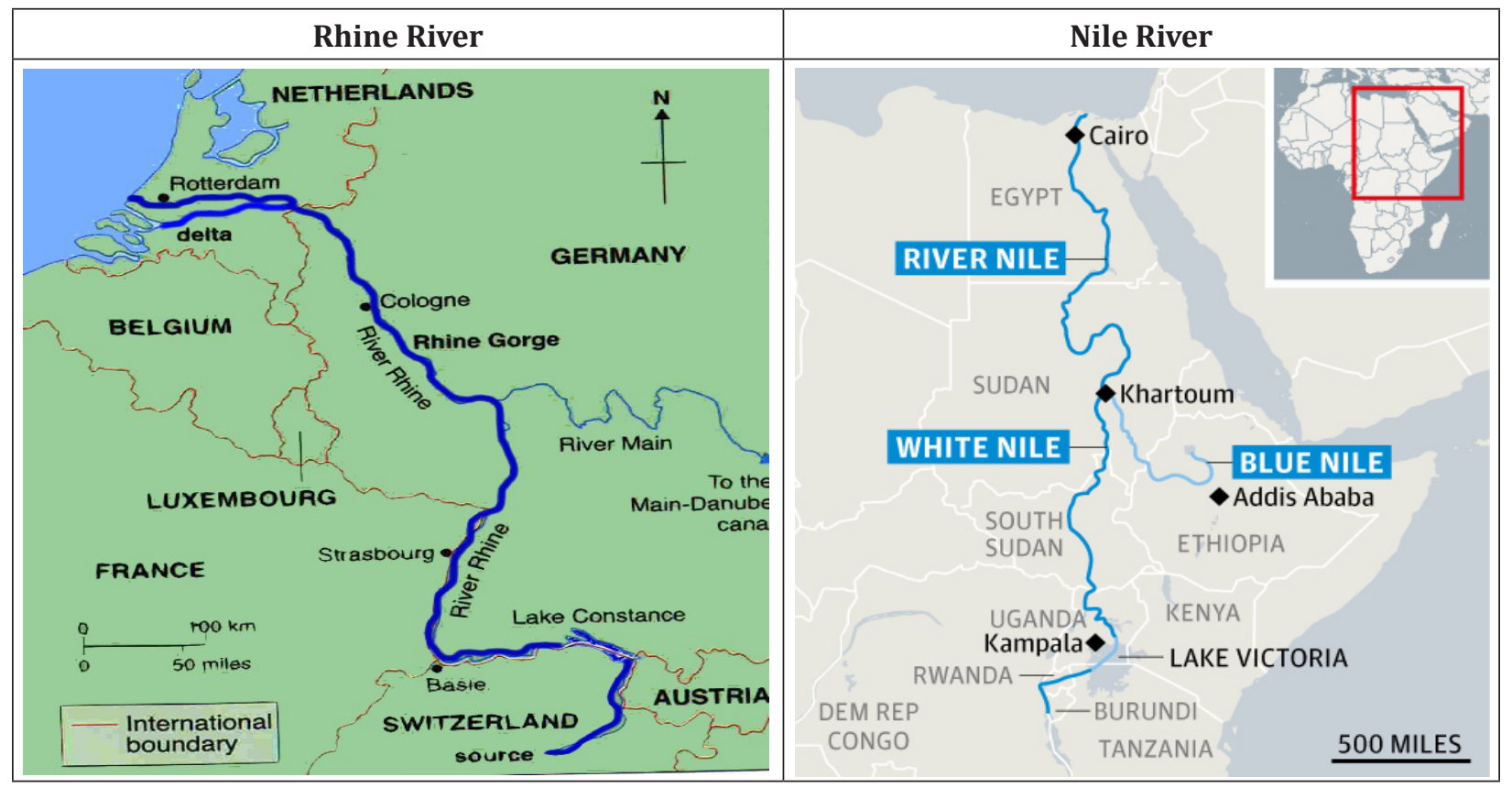

Source: google 
Hungary's 96 percent surface water comes from cross boundary. It has only 4 percent of the surface water which originates in its territory. Mozambique has less than 2 percent of surface water which is originating within the country (Koudstall \& Rijiberman, 1992). Mekong River flows through China, Myanmar, Laos, Thailand, Cambodia and Vietnam. The river acts as a main trade route between China and Southeast Asian countries. Colorado River is one of the main sources for agriculture, transportation and commerce for United States and Mexico. Nearly 40 million people rely on this river for their livelihoods and day to day survival (James et al, 2014). The upper basin of the Colorado River encompasses areas of Wyoming, Colorado, Utah and New Mexico whereas the lower basin covers Nevada, Arizona and California.

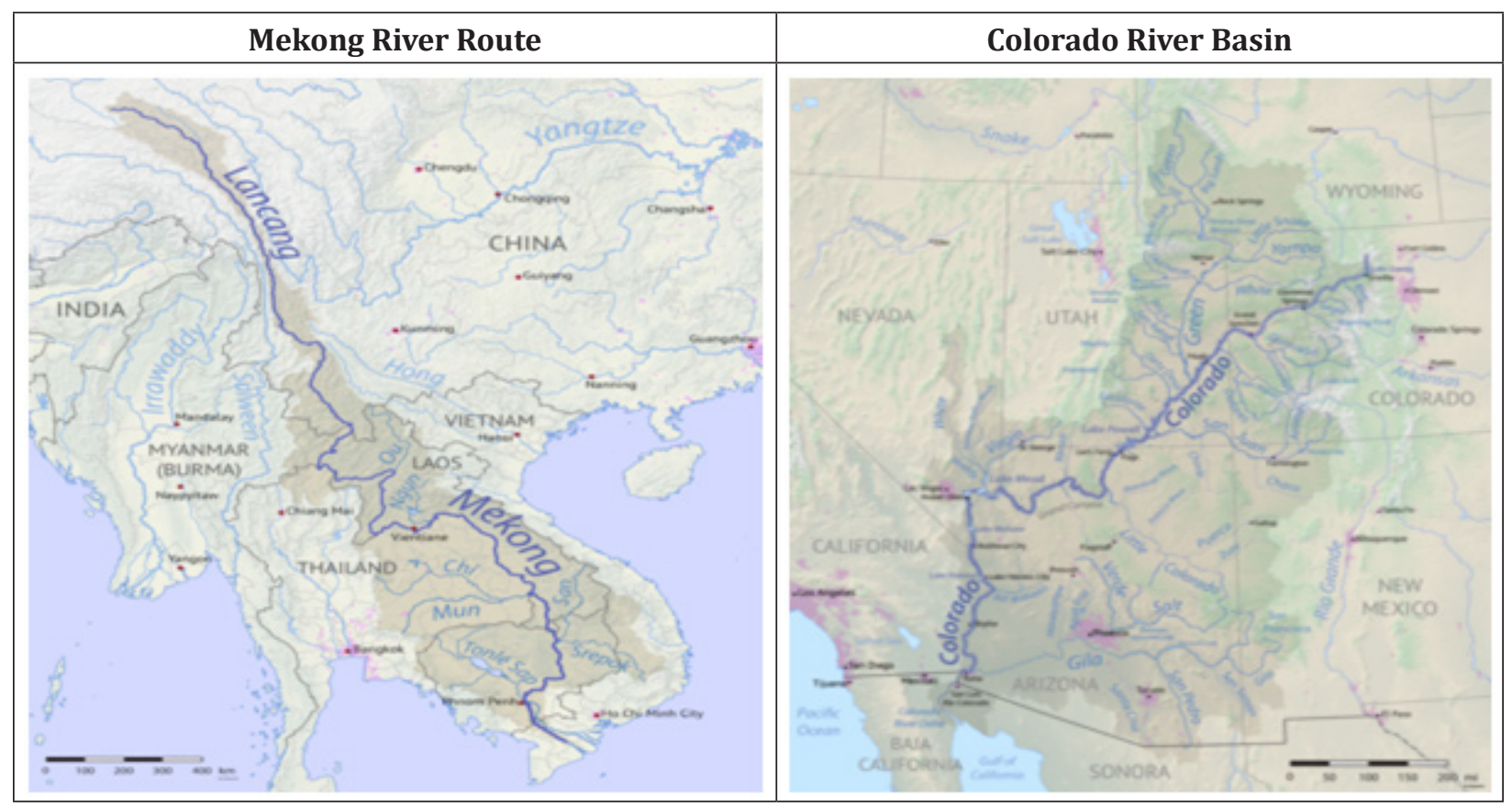

Source: google

The water of the river Brahmaputra is shared by India, Bhutan, China and Bangladesh whereas the river Ganga passes between India and Bangladesh and the water of this river has been distributed among both the countries. Danube River is a link between Germany, Austria, Slovakia, Hungary, Croatia, Serbia, Romania, Bulgaria, Moldova and Ukraine which share its water content for various purposes. There is no collective international law upon how the sharing of the benefits of such water resources should be done and the scarcity of water resources will keep on resulting in greater problems than before in internationally shared rivers. Though in 1966 the International Law Association (ILA) adopted the Helsinki Rules on the uses of waters of international rivers, but these do not speak about the independent aquifers and address only those which are connected to river (Koudstaal, 1992). The Berlin rules on water resources superseded the Helsinki rules in 2004 and speak on the fresh water resources whether these are within a nation or they are crossing international boundaries.

The competition to acquire more water resources has led to conflict between countries. Those which are already sharing water resources are fighting for the quantity and quality of its water content. For example- the Central Asian Republics too have been involved in conflict over sharing water of Amu Darya and Syr darya. Kazakhstan, Kyrgyzstan, Tajikistan, Turkmenistan and Uzbekistan are dependent on these sources of water for their survival. Since Tajikistan is an upper riparian country, it has proposed Rogun Dam in Amu Darya. The construction of this dam may hamper Uzbekistan's agricultural irrigation during summer and hydropower production during winter. Since Uzbekistan is world's second largest cotton producer, lack of water resources can reduce its production; which further would harm its economic development. Kyrgyzstan and Tajikistan 
argue over the allocation of irrigation water from the Syr Darya. The disagreements and conflicts resulted in the diversion of these two rivers (Amu darya and Syr Darya) to feed cotton and rice crops and now the flow of these two disappears in the desert (Hinrichsen \& Tacio, 2002).

According to a study conducted by Edwards, De Stefano, De Silva and Wolf, there were nearly 38 water sharing conflicts occurred between the years 1948 to 2008. Out of these 31 happened in Israel with its neighbours (Jacob et. al, 2017). The given table shows some of the water related disputes in various countries in the world.

The Middle East countries are facing severe water scarcity problem. Nearly 12 countries in this region are considered as water deficient countries with an availability of less than 500 cubic meters of renewable water resources per capita. The rainfall flows of Tigris and Euphrates Rivers are shared by Iran, Iraq, Turkey, Saudi Arabia and Syria. Iran, Turkey and Saudi Arabia are the upper riparian states and Iraq and Syria are the lower riparian. A number of causes have escalated water conflicts among these countries. Since these rivers are the main surface water source for Iraq, Syria and Turkey, they have never agreed to cooperate in sharing its water. And moreover, they have been involved in large scale water development projects. The tension caused by water sharing conflict reached to the verge of war during many occasions.

\section{Cooperation}

Water scarcity and polluted water are the two main problems today which every country needs to resolve. Declining water level and deforestation are the main issues to be handled at the government level. M.K. Gandhi was very well aware of such problems years back as he saw famines and drought due to lack of water resources. During the independence struggle at Kathiawar region in Gujarat, drought was experienced due to shortage of water. Gandhi asked for plantation of trees on a large scale as he knew that afforestation can be an effective step to solve the water crisis.

Research has shown that a precedent of coordination between stakeholders, through the establishment of institutional capacity in the form of agreements, treaties or informal working relationships, can help to reduce the likelihood of conflict. Countries which have signed treaties and agreements related to water sharing or other disputes are less prone to future conflicts related to water e.g. Indus water treaty between India and Pakistan.

Egypt and Sudan signed agreements in 1929 and 1959 on the allocation of Nile river water. The allocations were done on the basis of local needs, primarily those of agriculture. Egypt argued for a greater share of the Nile because of its larger population and extensive irrigation works. In 1959, Sudan and Egypt then divided future water for development equally between themselves.

A treaty was signed between Austria and Hungary on 4 September 1956 concerning the regulation of boundary water between both. The treaty speaks about the rights of $1 / 2$ of natural (not enhanced by artificial means) flow to each party from rivers which flow along the boundary, "without prejudice to acquired rights," upstream state of watercourse which intersect boundary may not decrease flow by more than $1 / 3$ and no development could take place without the joint approval (Wolf, 2001).

Jordan and Israel share two largest streams in the Jordan River basin namely the Jordan River and Yarmouk River. There was a serious dispute between these countries on the allocations of these water resources. Each country saw these resources as their own water. The challenges occurred from 1948 to 1994, when both countries were managing the available water at their own for their development requirements and needs and tried to utilize the available water which further led to the destruction of eco system and hampered their own water security. However, in 1994 Jordan and Israel decided to cooperate with each other and signed a peace treaty which included an agreement on the sharing of water. Annexure II of the treaty discusses about the sharing of water and related matters. In accordance to the article 6 of the treaty, Jordan and Israel agreed to cooperate 
on the exchange of relevant data on water resources and decided to establish a Joint Water Committee. Other articles dealt with the allocation, storage, water quality and protection etc. The treaty specified the quantity of the water for Israel and Jordan.

India and Pakistan are the best example of how trans-boundary water resources can be shared through cooperation. Both the countries are peacefully sharing the water of Indus River and its tributaries. The Indus Water Treaty was signed between India and Pakistan on 19 September 1960 with the help of World Bank. The treaty provides framework on the regulation of the Indus River water along with its tributaries and how it needs to be utilized in both countries. India has to take care of Sutlej, Ravi and Beas rivers whereas Jhelum, Indus and Chenab will be governed by Pakistan. India is allowed to use 20 percent water of Indus River which flows from her for irrigation, power generation as well as for transportation purposes. An arbitration mechanism has also been provided to solve all the disputes related to the treaty amicably.

Nepal is a landlocked country in South Asian region which is bordered by China in the north and India to the south, west and east. Nepal has water resources in abundance but it is handicapped in utilizing and managing the same due to lack of investment and technology. India and Nepal signed three major water deals namely Kosi agreement, Gandak Treaty and Mahakali Treaty. The Kosi and Gandak agreements were initially signed in 1954 and 1959 which were later amended in 1966 and 1964 due to Nepali concerns. The Mahakali treaty was signed in 1996 and ratified in 1997. These agreements protected Nepal from the floods due to overflow of the Kosi River, provided irrigation facilities and hydropower to Nepal.

Kunene River is a water resource for South African countries. An agreement was signed in 1969 between South Africa and Portugal for the water resources development of the Kunene River Basin which discusses on how to regulate the Kunene River flow; it focuses on the enhancement of hydro-electric power generation in the power plant situated at Matala, water supply purely uninterrupted for the purposes of irrigation and as well for human and animal needs, the generation of hydro-electric power at Ruacana (FAO, 1997). The agreement also covered following infrastructures: a) a dam at Gove in Angola, completed in 1975, to regulate the flow of the Kunene River, b) a dam at Calueque upstream from Ruacana power station, c) a hydro-electric power station at Ruacana with a capacity to generate 240 MW (completed in 1978) to supply South West Africa and Southern Angola with electricity and d) a pumping station at Calueque for irrigation of Ovamboland (Miessner, 2016).

Mekong River basin is an international water management regime in Southeast Asia which exists since 1957. The 1995 Mekong Agreement embodies many of the principles of the United Nations' 1997 'Convention on the law of Non-Navigational Uses of International Water Courses. It was signed between Cambodia, Laos, Thailand, Vietnams (Priscoli \& Wolf, 2008). The agreement speaks on how the sustainable development of the Mekong basin can take place with cooperation. The main objectives of the agreements are: To cooperate in all fields of sustainable development, utilization, management and conservation of the water and related resources of the Mekong River Basin including, but not limited to irrigation, hydro-power, navigation, flood control, fisheries, timber floating, recreation and tourism, in a manner to optimize the multiple-use and mutual benefits of all riparians and to minimize the harmful effects that might result from natural occurrences and man-made activities (MRC, 1995); To promote, support, cooperate and coordinate in the development (MRC, 1995); To protect the environment, natural resources, aquatic life and conditions, and ecological balance of the Mekong River Basin from pollution or other harmful effects (MRC, 1995); To cooperate on the basis of sovereign equality and territorial integrity in the utilization and protection of the water resources of the Mekong River Basin (MRC, 1995); To utilize the waters of the Mekong River system in a reasonable and equitable manner in their respective territories (MRC, 1995); To make every effort to avoid, minimize and mitigate harmful effects; freedom of navigation shall be accorded throughout the mainstream of the Mekong River (MRC, 1995). The signing of the 1995 Mekong agreement was a great success. It was recognised by the lower riparian countries in Mekong basin that the cooperation can manage very well the river related issues and also can avoid conflicts (Campbell, 2011). 


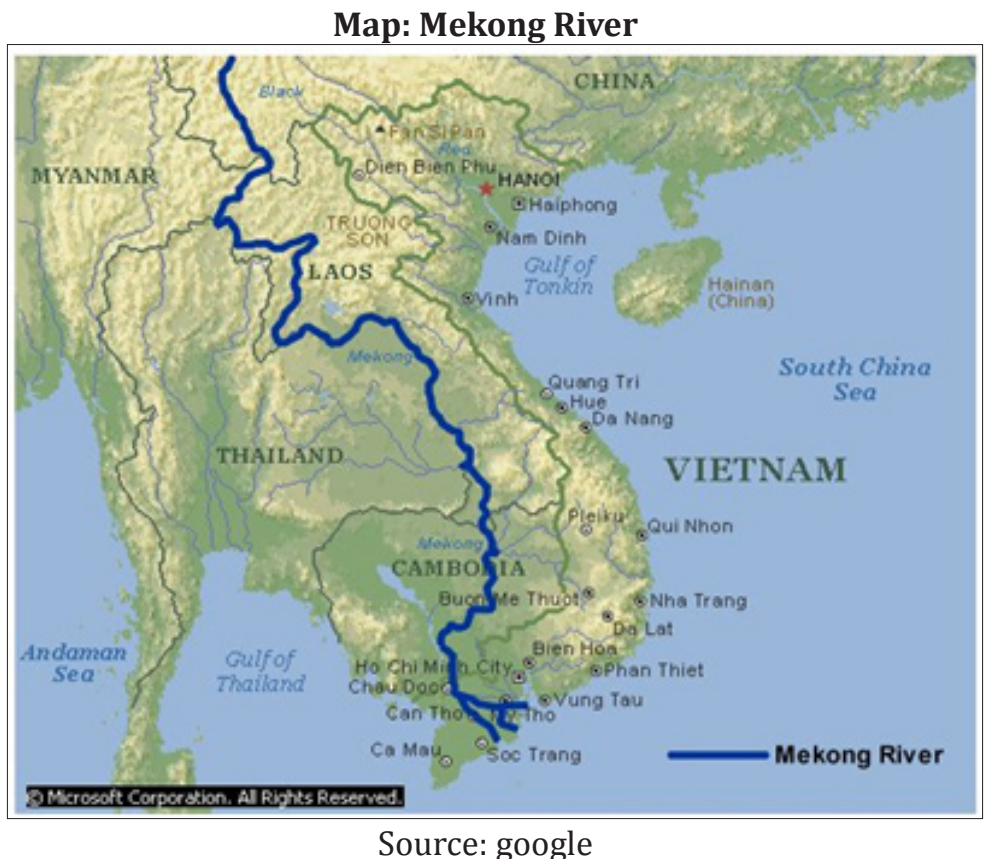

In 1994, a Peace Treaty was signed between Israel and Jordan. Later in 1995, Israel signed the Oslo II Agreement (Israel-Palestinian Interim Agreement) with Palestine which deals with issues on water between the agreement parties. Article 40 of the agreement's Annex III speaks on Water and Sewage as it is entitled with the same. The agreement is more comprehensive (Shamir, 1998). The issues related to water and sewage especially which sewage poses to the water resources and environment are being dealt together. The agreement does not merely want both the parties to divide the available water resources but encourages to developing additional resources for water. Therefore, with proper cooperation many of the issue related to water can be solved easily.

Signing and implementation of the treaties on water resources is the best institutional mechanism to mitigate the conflict related to water. A study conducted by A.T. Wolf analysed that the treaties can have positive impact on the levels of conflict/cooperation. According to him, the basins which do not come under any treaty were significantly more conflictive than basins with the treaties (Wolf, 2003). Therefore treaties and agreements can help in resolving the conflict and a positive level of cooperation can be maintained between the conflicting countries. With this method one of the goals of sustainable development can be achieved.

\section{Opportunities}

Water can act as a tool for peace-building between various countries. The Trans-boundary rivers or other water resources between upper and lower riparian countries can be shared equally or on the basis of needs, in this way cooperation can be sorted out. An early coordination between conflicting parties can help in working out the problem. Moreover, cooperation on water resources can provide opportunities for building trust, shared economic development and sustainable water management beyond national boundaries. Water is a useful incentive through which dialog and collaborations can take place; it can also contribute in settings of intense political tensions.

There is serious concern of gradual decrease in water quantity and quality which may cause internal instability in a country in future. It can also become a reason of conflict between particular groups or within states which can further affect the security environment at international level. 


\section{SUgGESTIVE MEASURES}

Following measures can successfully achieve the goals of sustainable development in water resources and also avoid conflicts over water:-

- trees plantation can help in to store the water resources.

- there should be proper implementation of water Act.

- Dams construction needs to be done without causing environmental issues.

- the use of chemicals should be minimized in order to control the level of water pollution.

- government should bring awareness among the common masses for less wastage and consumption of water

- $\quad$ water sharing should be done on equal basis for proper utilization and to solve the conflicts.

- there should purification of the water resources so that these can be reused for various purposes.

- the rivers should be interlinked to protect the water resources.

Global water crisis is a serious concern to human security. Millions of people lack access to sufficient quantity of fresh and safe water for their well being. At present this is the greatest threat humans are facing. To counter the threat of water crisis and conflict, countries should frame better policies for the management of scarce water resources. A Swedish hydrologist Malin Falkenmark also warned about the water crisis. He said, "We have to stop living as if we had unlimited water supplies and start recognizing that we must deal with serious water constraints." (Hinrichsen \& Tacio, 2002)

\section{CONCLUSION}

Water management is significant for achieving sustainable development as "sustainability is not just minimizing the personal needs; it is optimizing them for the future generations. If we manage water resources now then only we will be able to save it for our future. In this context a quote of M.K. Gandhi perfectly fits in here who once said, "The earth, the air, the land and the water are not an inheritance from our fore fathers but on loan from our children. So we have to handover to them at least as it was handed over to us." If we maintain and sustain the available water resources at present only then we and the generations to come will be able to use it for long term in the future. And countries should also make efforts to keep all the resources of water clean so that living beings can use it for their survival now and in the coming future. This goal of sustainable water security can be achieved with mutual cooperation only. Therefore the water resources should be converted in to a source and opportunity for cooperation rather than merely conflict for sustainable development.

\section{REFERENCES}

1. Campbell, Ian C., Managing International River Basins: Successes and failures of Mekong River Commission, in Grafton, R. Quentin and Hussey, Karen, Water Resources Planning and Management, Cambridge: Cambridge University Press, 2011, pp. 724- 740.

2. Carty, W., Towards an urban world, Earthwatch 43, 1991, pp. 2-4.

3. Chaturvedi, AK, Water: A Source for Future Conflicts, New Delhi: Vij Books, 2013, pp. 96-190.

4. Clinton, Hillary, A Statement on Water. Washington, D.C.: U.S. Department of State, 2010, March 22, Retrieved September 23, 2018 from http://www.state.gov/e/oes/water/ 
Sustainable Development and Water: Source of Conflict or Opportunity for Cooperation

5. FAO Legislative Study (1997), Agreement Between the government of the republic of South Africa and the government of Portugal in regard to the first phase of development of the water resources of the Cunene river basin Lisbon, 21 January 1969, Food and Agriculture Organisation of the United Nations (FAO), Rome: Development Law Service, 1997. Retrieved on 23 September 2018 from http://www.fao.org/docrep/ W7414B/w7414b11.htm

6. Wolf, Aaron T., From Rights to Needs, in Feitelson, Eran, Haddad, Marwan, Management of Shared Groundwater Resources: The Israeli-Palestinian Case with an International Perspective, New York: Kluwer Academic Publishers, 2001, pp. 133-166.

7. Godschalk,Seakle KB, WaterConflict, 2007, http://www.enviropaedia.com/topic/default.php?topic_id=241 retrieved on 11 September 2018.

8. Hinrichsen, Don and Tacio, Henrylito D, The Coming Fresh Water Crisis are already Here. Finding the Source: The Linkage between Population and Water, 2002, pp. 1-26. Retrieved September 23, 2018, from https:// www.wilsoncentre.org/sites/default/files/popwawa2.pdf

9. Jacob D. Petersen-Perlman, Jennifer C. Veilleux \& Aaron, T. Wolf, International water conflict and cooperation: challenges and opportunities, Water International, Routledge, 2017, pp. 1-16, Retrieved on 5 March 2018 from http://www.transboundarywaters.orst.edu/publications/publications/Petersen-Perlman\%20et $\% 2$ 0al.\%20-\%202017\%20-\%20International\%20water\%20conflict\%20and\%20cooperation\%20chal.pdf

10. James, Tim, Evans, Anthony, Madley, Eva, Kelly, Cary, The Economic Importance of the Colorado River to the Basin Region, Arizona: Arizona State University, December 18, 2014, pp. 1-42. Retrieved on 20 September 2018 from http://azsmart-dev.wpcarey.asu.edu/wp-content/uploads/2015/01/PTF-Final-121814.pdf

11. Koudstaal, Rob, Rijsberman, Frank R. and Savenije, Hubert, Water and Sustainable Development, Natural Resources Forum, Butterworth- Heinemann Ltd., 1992 November, pp. 277-290.

12. Lefort, R., Down to the last drop. UNESCO Sources 84, 1996, p.7 (1-23), Retrieved on 28 September 2018 from http://unesdoc.unesco.org/images/0010/001046/104613E.pdf

13. Meissner, Richard, Hydropolitics, Interest Groups and Governance: The Case of the Proposed Epupa Dam, Switzerland: Springer, 2016, pp. 1-96.

14. Mekong River Commission (MRC), Agreement on the Cooperation for the Sustainable Development of the Mekong River Basin, 1995, pp. 3-5. Retrieved on 23 September 2018 from http://www.mrcmekong.org/ assets/Publications/policies/agreement-Apr95.pdf

15. Molen, Irna Van der and Hildeering, Antoinette, Water: cause of conflict or co-operation?, Journal on Science and World Affairs, Vol. 1, No. 2, 2005, pp. 133-143

16. Niemczynowicz, Janusz, Wasted Waters. Down to the last drop, UNESCO Sources No. 84, 1996, p. 8. (1-23) Retrieved on 28 September 2018 from http://unesdoc.unesco.org/images/0010/001046/104613E.pdf

17. Ohlsson, Leif, Water and Conflict. Water and Development, in Marquette, Catherine M, (ed.), Encylopedia of Life Support Systems Volume II, Oxford: Eolss, 2009, pp 45-61.

18. Priscoli, J.D., Wolf, Aaron T., Managing and Transforming Water Conflicts, New York: Cambridge University Press, 2008, pp. 1-354.

19. Serageldin, I., Toward Sustainable Management of Water Resources, Washington, DC: World Bank, 1995, pp. $1-33$ 
Sustainable Development and Water: Source of Conflict or Opportunity for Cooperation

20. Shamir, Uri, Water Agreements between Israel and Its Neighbours, Transformation of Middle eastern natural environments: Legacies and Lessons, Bulletin 103, Yale F\&ES, 1998, pp. 274-296, retrieved on 23 September 2018 from https://environment.yale.edu/publication-series/documents/downloads/09/103shamir.pdf pp- 274-296.

21. Tao, F, Yokozawa, M, Hayashi Y and Lin E., Future Climate Change, the Agricultural Water Cycle, and Agricultural Production in China, Agriculture, Ecosystems \& Environment, Vol. 95 No.1, 2003, pp. 203-215.

22. Wolf, A.T., International Water: Identifying basins at risk. Water Policy, Vol. 5, Issue 1, London: IWA Publishing, 2003, pp. 29-60

Citation: Dr. Neeta Rani. "Sustainable Development and Water: Source of Conflict or Opportunity for Cooperation" American Research Journal of Humanities and Social Sciences, vol 4, no. 1, 2018, pp. 1-11.

Copyright (C) 2018 Dr. Neeta Rani, This is an open access article distributed under the Creative Commons Attribution License, which permits unrestricted use, distribution, and reproduction in any medium, provided the original work is properly cited. 